\title{
Prostate transglutaminase (TGase-4) antagonizes the anti-tumour action of MDA-7/IL-24 in prostate cancer
}

Richard J Ablin ${ }^{1 *}$, Howard G Kynaston², Malcolm D Mason² and Wen G Jiang ${ }^{2}$

\begin{abstract}
Background: Transglutamiase-4 (TGase-4), also known as prostate transglutaminase, belongs to the TGase family and is uniquely expressed in the prostate gland. The functions of this interesting protein are not clearly defined. In the present study, we have investigated an unexpected link between TGase-4 and the melanoma differentiationassociated gene-7/interleukin-24 (MDA-7/IL-24), a cytokine known to regulate the growth and apoptosis of certain cancer and immune cells.
\end{abstract}

Methods: Frozen sections of normal and malignant human prostate tissues and human prostate cancer (PCa) cell lines PC-3 and CA-HPV-10, cell lines expressing low and high levels of TGase-4, and recombinant MDA-7/IL-24 (rhMDA-7/IL-24) were used. Expression construct for human TGase-4 was generated using a mammalian expression vector with full length human TGase-4 isolated from normal human prostate tissues. PC-3 cells were transfected with expression construct or control plasmid. Stably transfected cells for control transfection and TGase-4 over expression were created. Similarly, expression of TGase-4 in CA-HPV-10 cells were knocked down by way of ribozyme transgenes. Single and double immunofluorescence microscopy was used for localization and colocalization of TGase-4 and MDA-7/IL-24 in PCa tissues and cells with antibodies to TGase-4; MDA-7/IL-24; IL20alpha; IL-20beta and IL-22R. Cell-matrix adhesion, attachment and migration were by electric cell substrate impedance sensing and growth by in vitro cell growth assay. A panel of small molecule inhibitors, including Akt, was used to determine signal pathways involving TGase-4 and MDA-7/L-24.

Results: We initially noted that MDA-7 resulted in inhibition of cell adhesion, growth and migration of human PCa PC-3 cells which did not express TGase-4. However, after the cells over-expressed TGase-4 by way of transfection, the TGase-4 expressing cells lost their adhesion, growth and migratory inhibitory response to MDA-7. On the other hand, CA-HPV-10 cells, a cell type naturally expressing high levels of TGase-4, had a contrasting response to MDA-7 when compared with PC-3 cells. Inhibitor to Akt reversed the inhibitory effect of MDA-7, only in PC-3 control cells, but not the TGase-4 expressing PC-3 cells. In human prostate tissues, TGase-4 was found to have a good degree of co-localization with one of the MDA-7 receptor complexes, IL-20Ra.

Conclusion: The presence of TGase-4 has a biological impact on a prostate cancer cell's response to MDA-7. TGase-4, via mechanism(s) yet to be identified, blocked the action of MDA-7 in prostate cancer cells. This has an important implication when considering the use of MDA-7 as a potential anticancer cytokine in prostate cancer therapies.

\footnotetext{
* Correspondence: ablinrj@email.arizona.edu

${ }^{1}$ Department of Pathology, University of Arizona College of Medicine, Arizona Cancer Center and BIO5 Institute, Tucson, Arizona, AZ 85724-5043

USA

Full list of author information is available at the end of the article
}

\section{Biomed Central}

(C) 2011 Ablin et al; licensee BioMed Central Ltd. This is an Open Access article distributed under the terms of the Creative Commons Attribution License (http://creativecommons.org/licenses/by/2.0), which permits unrestricted use, distribution, and reproduction in any medium, provided the original work is properly cited. 


\section{Background}

Transglutaminases (EC 2.3.2.13) catalyze the posttranslational modification of proteins by the formation of epsilon-(gamma-glutamyl) lysine isopeptide bonds [1]. A number of human transglutaminases (TGases), as reviewed [2] have been identified and shown to have relatively restrict distribution patterns. The intracellular forms are: tissue TGase (TGase-2), keratinocyte TGase, and hair follicle TGase; extracellular TGases include factor XIIIa (plasma TGase) and prostate TGase (TGase-4, or TGaseP). In the case of TGase-4, the focus of this study, the gene is located to 3p22-p21.33 [3] and by analysis of somatic cell hybrids, mapped to chromosome 3 [3-5]. TGase-4 has a strong pattern of distribution in the prostate [6-8].

The function of the TGase- 4 is not clear. The rat homologue homologue of TGase-4 (dorsal prostate TGase or Dorsal protein 1 [DP1]) has been suggested to be responsible for the cross-linking during the copulatory plug [9] formation and may be involved in sperm cell mobility and immunogenicity to some degree $[10,11]$. In initial studies by others [6,7], TGase-4 expression was restricted to luminal epithelial cells. The expression pattern as observed for TGase-4 has not been found thus far for any other prostate-specific marker [6]. However, the function of this enzyme in prostate cancer is unclear. Recently, it has been shown that TGase- 4 is linked to the invasiveness of prostate cancer cells [12] and participates in the regulation of the interactions between prostate cancer cells and endothelial cells, the later involving the Rock signalling pathway [13]. In addition, variants of TGase- 4 have been recently reported in benign and malignant human prostate tissues [14].

As part of our continuing studies to investigate proteins interacting with TGase-4 using immunoprecipitation of proteins from the prostate gland, we identified a small panel of proteins that interacted with TGase-4, including RON (the HGF-like protein receptor) [15]. MDA-7 was one of the other proteins precipitated with TGase-4.

MDA-7 (melanoma differentiation associated gene-7), also known as IL-24, was initially identified from cancer cells and found to be up-regulated in melanoma cells [16]. Forced expression of MDA-7 in cancer cells was found to be growth inhibitory [17]. The human MDA-7 gene, mapped to 1q32.2-q41, encodes a protein with a predicted size of $23.8 \mathrm{kD}$. The secreted mature MDA-7 is a $35-40$ kDa phosphorylated glycoprotein. Cell types known to express MDA-7 are diverse, including B cells, NK cells, dendritic cells, monocytes, melanocytes and melanoma cells. It is now known that MDA-7 is a differentiation-, growth-, and apoptosis-associated gene with potential utility for the gene-based therapy of diverse human cancers. The location of the MDA-7 gene is closely linked to the
IL-10, IL-19, and IL-20 genes within a 195-kb region -the IL-10 family cytokine cluster. MDA-7/IL-24 functions in cells via its receptor, MDA-7R/IL-24R. The MDA-7 receptor complexes include at least the IL-20alpha and IL20beta complex and the IL-22R and IL-20Rbeta complex. Limited information is available on the effect of MDA-7 on prostate cancer cells. Studies of adenoviral vectorinduced expression of MDA-7 in human prostate cancer cells demonstrated varying degree of inhibition of growth and induction of apoptosis. It is interesting to note that $\mathrm{Bcl}-2$ and $\mathrm{Bcl}-\mathrm{xL}$ may differentially protect human prostate cancer cells from MDA-7 induced apoptosis [18].

In the present study, we have evaluated the biological impact of TGase-4 and MDA-7 and herein report a link between MDA-7 and TGase- 4 in prostate cancer cells and tissues. In the course thereof, we have further found that the effect of MDA-7 on prostate cancer cells is dependent on the presence of TGase- 4 in the cell.

\section{Materials and methods}

\section{Materials and cell lines}

Human prostate cancer cells, PC-3 and CA-HPV-10 were from ATCC (American Type Cell Collection, Manassas, VA, USA). Fresh frozen human prostate tissues were collected from University Hospital of Wales under the approval of the local ethical committee, obtained immediately after surgery and stored at $-80^{\circ} \mathrm{C}$ until use.

Recombinant human MDA-7/IL-24 was purchased from R\&D Systems Europe (Abingdon, Oxon, UK). Antibodies to human MDA-7/IL-24, anti-IL-20Ralpha, anti-IL20Rbeta, and anti-IL-22R were from Santa-Cruz Biotechnologies, Inc. (Santa Cruz, CA, USA) Two antibodies to human TGase-4 were respectively purchased from Covalab (Axxora Platform, Nottingham, UK) and ABCAM (Cambridge, UK). ROCK inhibitor was from Santa-Cruz Biotechnologies, Inc. (Santa Cruz, CA, USA), Akt inhibitor, SIS3 inhibitor, PLC-gamma inhibitor, JNK inhibitor, JAK inhibitor, MET inhibitor, Wortmannin, and Wiskostatin were from Calbiochem (Nottingham, UK). Matrigel (reconstituted basement membrane) was purchased from Collaborative Research Products (Bedford, MA, USA). Transwell plates equipped with a porous insert (pore size $8 \mu \mathrm{m}$ ) were from Becton Dickinson Labware (Oxford, UK). DNA gel extraction and plasmid extraction kits were from Sigma (St. Louis, MO, USA).

\section{Construction of hammerhead ribozyme transgenes targeting the human TGase- 4 and mammalian expression vector for human TGase-4}

Hammerhead ribozymes that specifically target a GTC site of human TGase-4 (GenBank accession NM_003241), based on the secondary structure of TGase-4, were generated as previously described $[12,19]$. Touch-down PCR 
was used to generate the ribozymes with the respective primers (Table 1). This was subsequently cloned into a pEF6/V5-His vector (Invitrogen, Paisley, Scotland, UK; selection markers: ampicillin and blasticidin, for prokaryotic and mammalian cells, respectively), and amplified in $E$. coli, purified, verified and used for electroporation of prostate cancer cells. Following selection of transfected cells with blasticidin (used at $5 \mu \mathrm{g} / \mathrm{ml}$ ) and verification, the following stably transfected cells were established: TGase-4 knock-down cells (designated here as CA-HPV-10 ${ }^{\triangle T \text { TGase4 }}$ in this manuscript), plasmid only control cells (CA-HPV$10^{\mathrm{pEFa}}$, and the wild type, CA-HPV- $10^{\mathrm{WT}}$. The CA-HPV$10^{\triangle \mathrm{TG} \text { ase }}$ and the CA-HPV- $10^{\mathrm{pEFa}}$ cells thus created were always kept in a maintenance medium which contained $0.5 \mu \mathrm{g} / \mathrm{ml}$ blasticidin. A mammalian TGase-4 expression construct was prepared as previously reported [15]. PC-3 cells which express little TGase-4 were transfected with either the control vector or TGase-4 expression vector. Stably transfected cells were designated as $\mathrm{PC}-3^{\mathrm{PEF} / \mathrm{His}}$ and PC-3 ${ }^{\text {TGase4exp }}$, for control transfection and TGase-4 expression, respectively. Pooled populations of genetically manipulated cells from multiple clones were used in the subsequent studies.

\section{RNA preparation and RT-PCR}

RNA from cells was extracted using an RNA extraction kit (AbGene Ltd, Surrey, UK) and the concentration quantified using a spectrophotometer (Wolf Laboratories, York, UK). cDNA was synthesised using a first strand synthesis with an oligo ${ }^{\mathrm{dt}}$ primer (ABgene, Surrey, UK). PCR was performed using sets of primers (Table 1) with the following conditions: $5 \mathrm{~min}$ at $95^{\circ} \mathrm{C}$, and then $20 \mathrm{sec}$ at $94^{\circ} \mathrm{C}-25$ sec at $56^{\circ} \mathrm{C}, 50 \mathrm{sec}$ at $72^{\circ} \mathrm{C}$ for 36 cycles, and finally $72^{\circ} \mathrm{C}$ for $7 \mathrm{~min}$. B-actin was amplified and used as a house keeping control. PCR products were then separated on a $0.8 \%$ agarose gel, visualized under UV light, photographed using a Unisave ${ }^{\mathrm{TM}}$ camera (Wolf Laboratories, York, UK) and documented with Photoshop software.

\section{Quantitative analysis of TGase-4}

The level of the TGase- 4 transcripts in the above-prepared cDNA was also determined using a real-time quantitative
PCR, based on the Amplifluor ${ }^{\mathrm{TM}}$ technology modified as previously reported $[19,20]$. Briefly, pairs of PCR primers were designed using the Beacon Designer ${ }^{\mathrm{TM}}$ software (version 2, Palo Alto, CA, USA), but added to one of the primers was an additional sequence, known as the $\mathrm{Z}$ sequence (5'actgaacctgaccgtaca'3) which is complementary to the universal $\mathrm{Z}$ probe (Intergen Inc., Oxford, UK). A Taqman detection kit for $§$-actin was purchased from Perkin-Elmer. The reaction was carried out using the following: Hot-start Q-master mix (ABgene, Surrey, UK), 10 pmol of specific forward primer, 1 pmol reverse primer which has the $\mathrm{Z}$ sequence (underlined [Table 1]), $10 \mathrm{pmol}$ of FAM-tagged probe, and cDNA generated from approximate 50 ng RNA. The reaction was carried out using IcyclerIQ $^{\text {TM }}$ (Bio-Rad, Hammel Hemstead, UK) which was equipped with an optic unit that allows real time detection of 96 reactions. The following condition was used: $94^{\circ} \mathrm{C}$ for $12 \mathrm{~min}, 50$ cycles of $94^{\circ} \mathrm{C}$ for $15 \mathrm{sec}, 55^{\circ} \mathrm{C}$ for $40 \mathrm{sec}$ and $72^{\circ} \mathrm{C}$ for $20 \mathrm{sec}$. The levels of the transcripts were generated from an internal standard that was simultaneously amplified with the samples.

\section{In vitro cell growth assay}

Cells were plated into 96-well plated at 2,000 cells/well followed by a period of incubation. Cells were fixed in $10 \%$ formaldehyde on the day of plating and daily for the subsequent 5 days. $0.5 \%$ crystal violet $(\mathrm{w} / \mathrm{v})$ was used to stain cells. Following washing, the stained crystal violet was dissolved with $10 \%(\mathrm{v} / \mathrm{v})$ acetic acid and the absorbance was determined at a wavelength of $540 \mathrm{~nm}$ using an ELx800 spectrophotometer. Absorbance represents the cell number.

\section{Electric Cell-substrate Impedance Sensing (ECIS) based cell adhesion assay}

Two models of ECIS instrument were used: ECIS 9600 for screening and ECIS1600R for modeling. In both systems, $8 \mathrm{~W} 10$ arrays were used (Applied Biophysics Inc, Troy, NY, USA) [21,22]. Following treatment of the array surface with a Cysteine solution, the arrays were incubated with complete medium for $1 \mathrm{hr}$. The same number of prostate cancer cells, $\mathrm{PC}-3^{\mathrm{PEF} / \mathrm{His}}, \mathrm{PC}-3^{\mathrm{TG} \text { Gase4exp }}$, or PC- $3^{\text {wt }}$ when appropriate CA-HPV-10 ${ }^{\triangle \mathrm{TG} \text { ase }} 4$, CA-HPV$10^{\mathrm{pEF} / \mathrm{His}}$ or CA-HPV-10 ${ }^{\mathrm{wt}}(300,000$ per well) were added

Table 1 Primer and oligo sequences for PCR, ribozyme and amplification of full coding sequence of prostate transglutaminase (TGase-4)

\begin{tabular}{|c|c|c|}
\hline & Sense $\left(5^{\prime}-' 3\right)$ & AntiSense $\left(5^{\prime}-{ }^{\prime} 3\right)$ \\
\hline TGase-4 expression & Atgatggatgcatcaaaaga & Ctacttggtgatgagaacaatcttctga \\
\hline TGase-4 (position 62) & Atggatgcatcaaaagagc & $\begin{array}{l}\text { Aggtgaaacacctgtcctc } \\
\text { (Aactgaacctgaccgtacaaggtgaaacacctgtcctc [for Q-PCR]) }\end{array}$ \\
\hline TGase-4 (position 1957) & Ataaaatgcaccccaataaa & $\begin{array}{l}\text { Ctacttggtgatgagaacaatc } \\
\text { (Actgaacctgaccgtacacctacttggtgatgagaacaatc [for Q-PCR]) }\end{array}$ \\
\hline GAPDH & Agcttgtcatcaatggaaat & Cttcaccaccttcttgatgt \\
\hline GAPDH for Q-PCR & Ctgagtacgtcgtggagtc & Actgaacctgaccgtacacagagatgatgacccttttg \\
\hline
\end{tabular}


to each well. Electric changes were continuously monitored for up to $24 \mathrm{hr}$. In the 9600 system, the monitoring was at fixed $30 \mathrm{~Hz}$. In the 1600R system, two conditions were recorded: $400 \mathrm{~Hz}, 4,000 \mathrm{~Hz}, 40,000 \mathrm{~Hz}$ for screening the nature of resistance changes and $4,000 \mathrm{~Hz}$ fix frequency for cell modeling. For cell adhesion and motility modeling, we employed the $\mathrm{Rb}$ modeling methods provided by the software of ECIS-1600R, based on a method previously reported [23]. After recording adhesion and migration at 4,000 $\mathrm{Hz}$, cell behaviour was modeled using the $\mathrm{Rb}$ method by using a cell free well as a reference unit. Cell migration and adhesion are shown here as the resistance.

Immunofluorescence co-staining of TGase-4 and MDA-7 or MDA-7 receptors in cells and tissues

Frozen sections of human prostate tissues (normal and tumour) were sectioned at a thickness of $6 \mu \mathrm{m}$ using a cryostat. The sections were mounted on super frost plus microscope slides, air dried and then fixed in a mixture of $50 \%$ acetone and $50 \%$ methanol. The sections were then placed in "Optimax" wash buffer for 5-10 min to rehydrate. Sections were incubated for $20 \mathrm{~min}$ in a $10 \%$ horse serum blocking solution and probed with the primary antibodies (1:50 for anti-TGase-4, 1:100 for anti-MDA-7, anti-IL-20Ralpha, and 1:150 for anti-IL-20Rbeta and antiIL-22R). Following extensive washings, sections were incubated for $30 \mathrm{~min}$ in the secondary FITC- and TRITC conjugated in the presence of HOESCHT-33258 at $10 \mu \mathrm{g} / \mathrm{ml}$ (Sigma, St. Louis, MO, USA). Following extensive washings, the slides were mounted using Fluorosave ${ }^{\mathrm{TM}}$ mounting media (Calbiochem, Nottingham, UK) and allowed to harden overnight in the refrigerator, before being examined. Slides were examined using an Olympus fluorescence microscope and photographed using a Hamamatsu digital camera. The images were documented using the Cellysis software (Olympus, Bristol, England, UK).

Statistical analysis was carried out using Minitab. For normality test: Anderson-Darling test and for statistical difference Student's " $t$ " test.

\section{Results}

Over-expression of TGase-4 in prostate cancer cells diminishes the action of MDA-7/IL-24 in prostate cancer cells -Adhesion assays

We first created a set of cell sublines to over-express human TGase-4(PC-3 $\left.{ }^{\text {TGase4exp }}\right)$, from the prostate cancer cell line, PC-3, whose wild type had little expression of TGase-4. Using Quantitative RT-PCR analysis, PC- $3^{\text {TGa- }}$ se4exp cells were found to express significantly higher levels of TGase- 4 transcript (16.9 \pm 2.2 copies), compared with PC- $3^{\mathrm{PEF}}$ and $\mathrm{PC}-3^{\mathrm{wt}}\left(1.8 \pm 0.12\right.$ for $\mathrm{PC}-3^{\mathrm{wt}}$ and 2.1 \pm 0.53 copies for PC- $3^{\text {pEF6 }}, p<0.001$ vs PC- $3^{\text {TGase4exp }}$. The stably transfected cells were subject to testing for their adhesiveness. Figure 1 shows traces of Electric Cell-
Substrate Impedance Sensing (ECIS) from an adhesion assay (A and B-left 9600 and C- right 1600R modeling). Two cell types were directly compared: PC-3 overexpressing TGase4 (PC-3 ${ }^{\text {TGase4exp}}$ ) and control transfected cells $\left(\mathrm{PC}-3^{\mathrm{pEF} 6}\right)$. In control cells (A-top left), rhMDA-7/rhIL-24 resulted in a substantial inhibition of adhesion at $50 \mathrm{ng} / \mathrm{ml}$. PC- $3^{\text {TGase4exp }}$, which had rapidly increased its adhesion, failed to respond to rhMDA-7 (Bleft bottom). Using the $1600 \mathrm{R}$ and $\mathrm{Rb}$ based cell modeling ( $\mathrm{C}$-right), the same was clearly demonstrated.

\section{Over-expression of TGase-4 in prostate cancer cells} diminishes the action of MDA-7/IL-24 in prostate cancer cells -Motility assays

Here, an ECIS based wounding assay was used. Confluent monolayer cells were wounded at $6 \mathrm{~V}$ for $30 \mathrm{sec}$ which resulted in complete death of the cells over the electrode. The migration of healthy cells from the edge of the wounding to the wounding space was tracked. Similar to the changes seen with adhesion, over-expression of TGase-4 in PC-3 cells (PC-3 ${ }^{\text {TGase4exp }}$ ) rendered cells, lost their response to rhMDA-7 as shown in Figure 2. PC-3 cells showed a reduced motility in the presence of rhMDA-7 (50 ng/ml), however, the response was lost in PC- $3^{\text {TGase4exp }}$.

\section{A cell line naturally expressed TGase- 4 responded to rhMDA7/IL-24 differently from PC-3}

Of all the prostate cancer cell lines in our collection, CAHPV-10 is one that naturally expressed high levels of TGase-4 (TGase-4 transcript level in wild type being 15.8 \pm 2.3 copies) [12]. We therefore tested if this cell responded differently from $\mathrm{PC}-3$ cells, to the treatment of MDA-7. Unexpectedly, the CA-HPV-10 displayed, as shown in Figure 3, a very different response as evident in the two traces from 9600 (adhesion) and 1600R model (motility - wounding model). It is clear that CA-HPV-10 cells, which have high levels of TGase-4 responded to rhMDA-7 in a virtually reverse manner to PC-3, with an increased adhesion (top) and partly motility (wounding migration assay, bottom) (Figure 3).

\section{Effects of TGase-4 and MDA-7 on the growth of prostate cancer cells}

MDA-7 is known to have an inhibitory effect on the growth of certain cells, including some cancer cells. This was indeed seen with $\mathrm{PC}-3^{\mathrm{wt}}$ and $\mathrm{PC}-3^{\mathrm{PEF} 6}$ cells, as shown in Figure 4 (left). It is interesting to observe that the PC$3^{\text {TGase4exp }}$ cells have lost their response to rhMDA-7.

\section{Effects of TGase-4 expression and signalling pathways}

In order to determine the potential pathways by which TGase-4 may interrupt the action of MDA-7, we used a panel of small molecule inhibitors that are either 


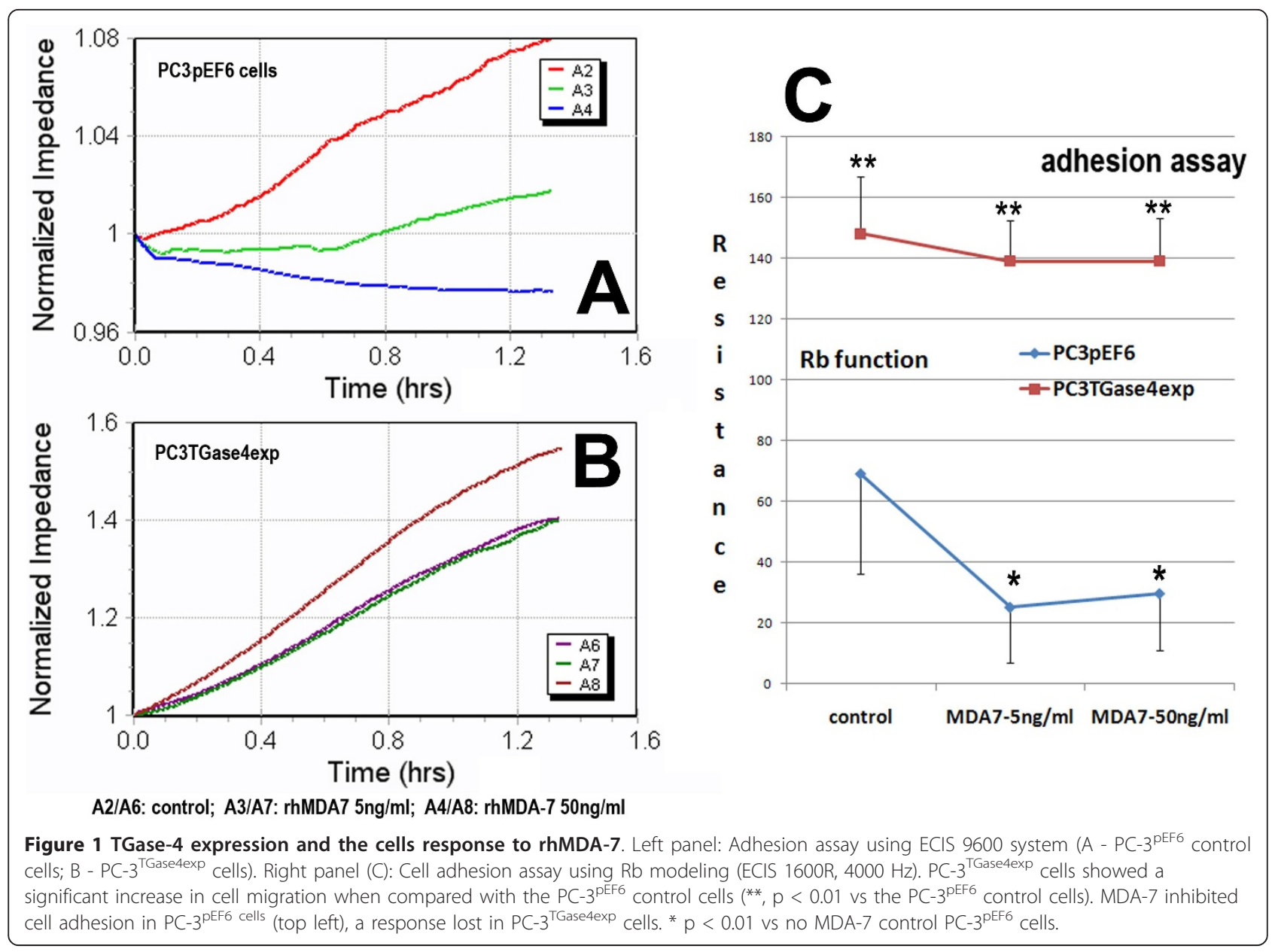

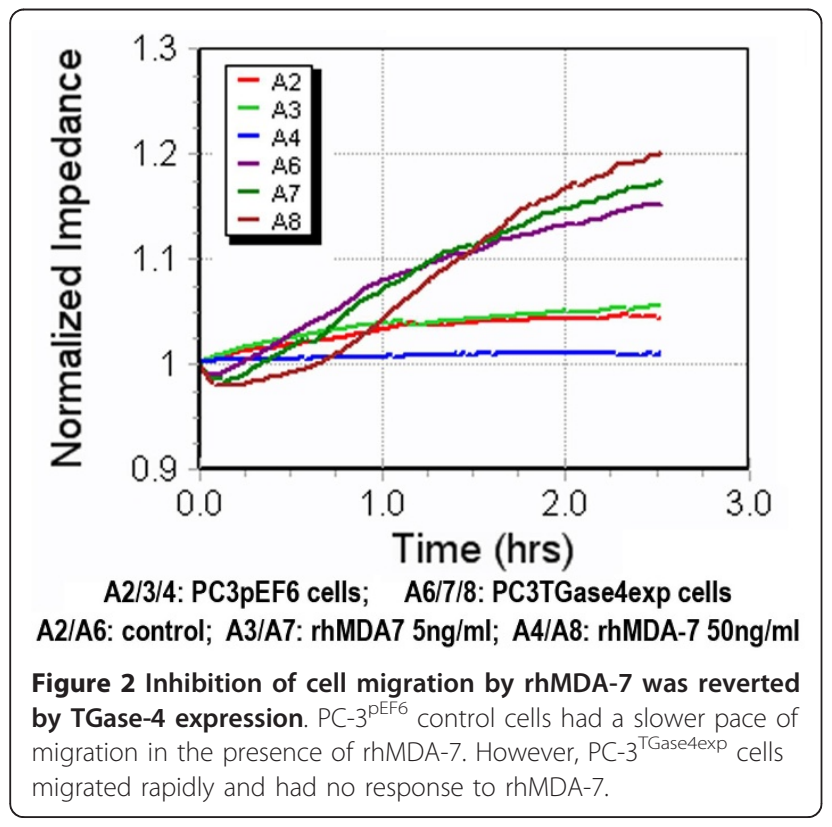

downsteam of the MDA-7 receptor pathways or known to be involved in the regulation of cell motility and growth. No significant effects were seen with the JNK inhibitor, JAK3 inhibitor, piceatannol, Wortmannin, MET inhibitor and SIS3. However, it is interesting to note that the Akt inhibitor reversed the inhibitory effects of rhMDA-7 on control PC-3 cells, but had no effect on PC-3 ${ }^{\text {TGase4exp }}$ cells (Figure 4 right).

\section{Cellular co-distribution of TGase-4 and MDA-7/IL-24 in prostate cancer cells}

We have stained MDA-7 in prostate cancer cells. Shown in Figure 5A, PC-3 wild type cells stained for MDA-7, mostly in the cytosolic region and perinucleus areas. Over-expression of TGase-4 in the cells appeared to reduce the cytosolic staining of MDA-7 (Figure 5A).

Tissue co-localization of TGase- 4 and MDA-7/IL-24 in prostate cancer tissues

By application of double-immunofluorescent staining, we also attempted to determine if TGase-4 and MDA-7, 

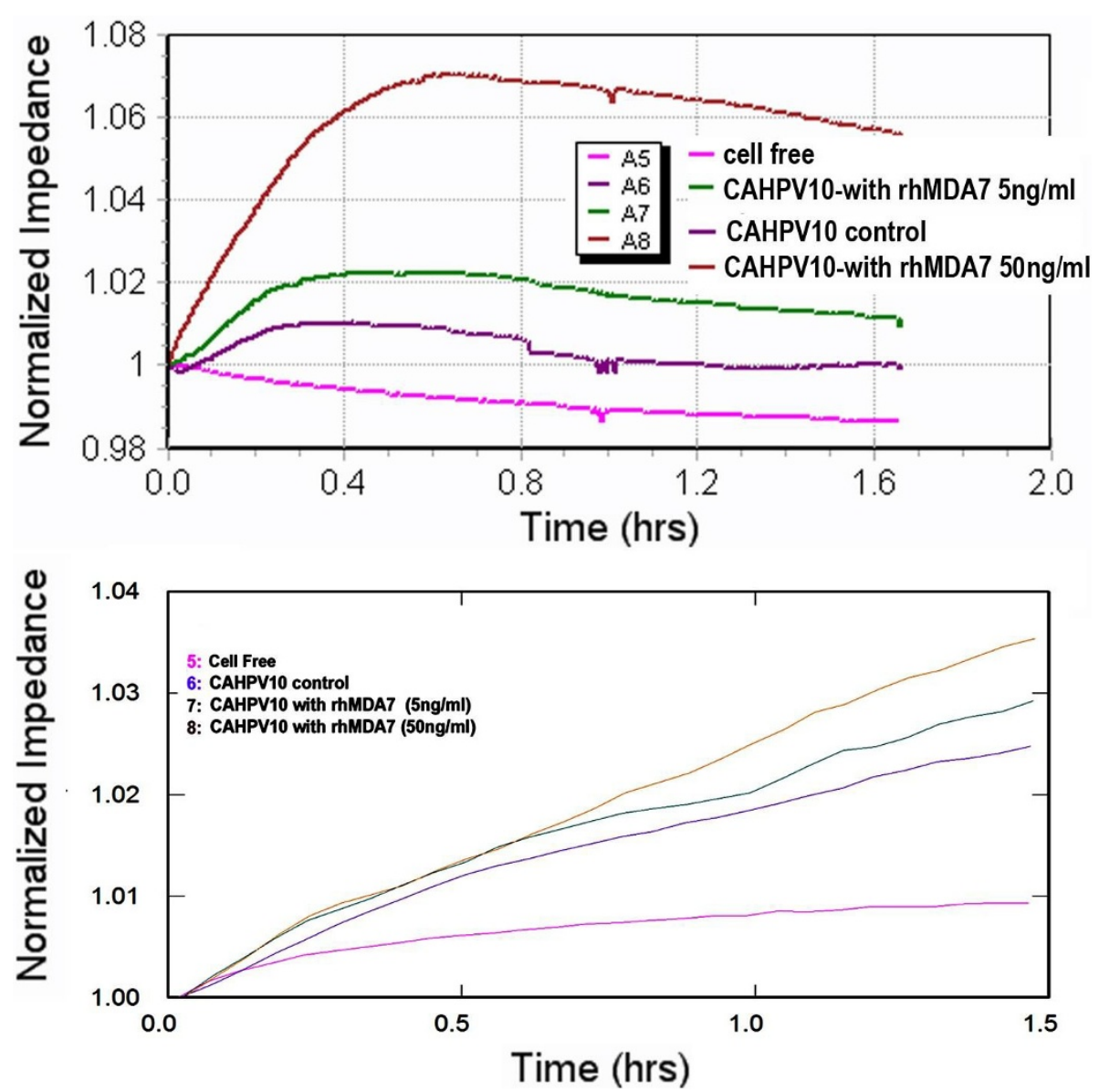

Figure 3 Response to rhMDA-7 in cell adhesion (top) and migration (bottom) by CA-HPV-10 wild type cells, a cell with high levels of expression of TGase- 4 .
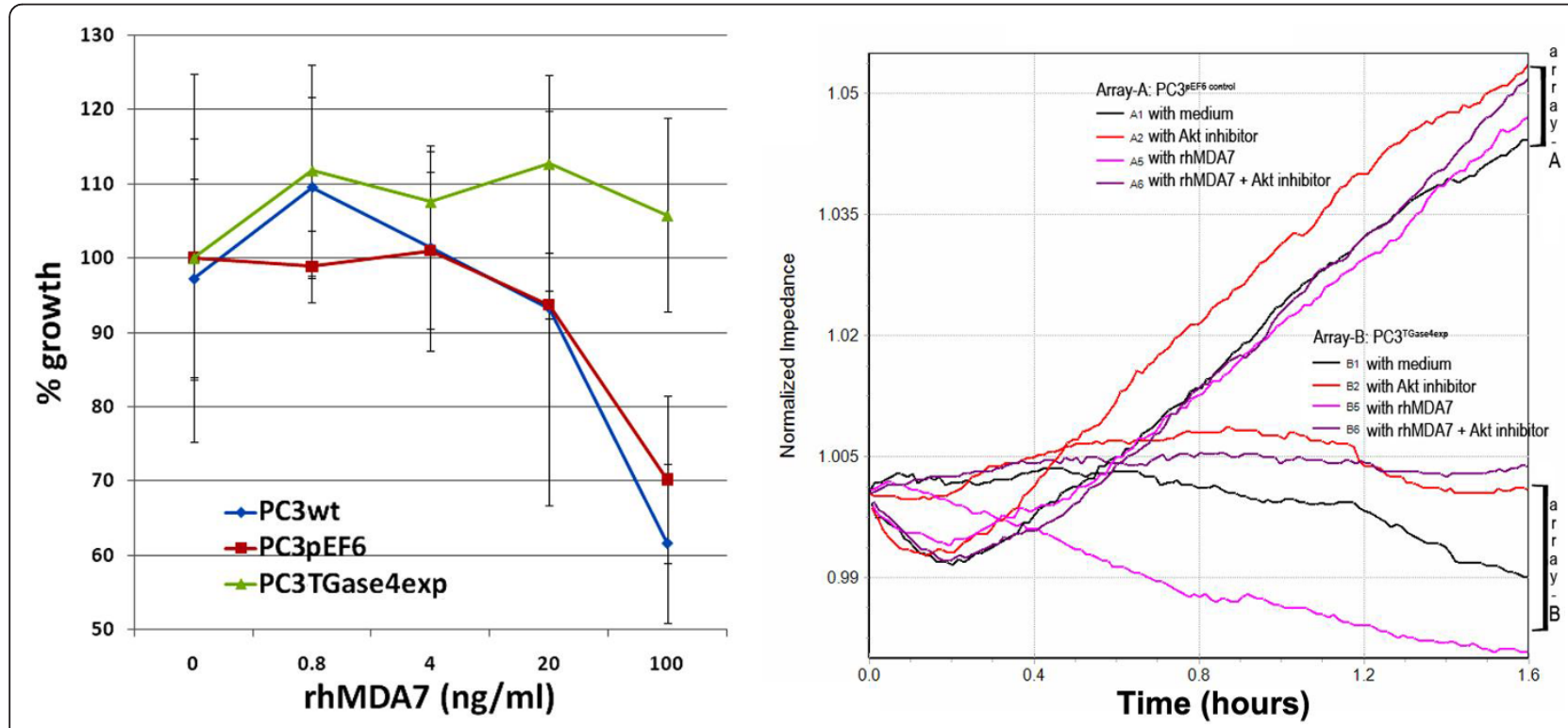

Figure 4 Effects of rhMDA-7 on the in vitro growth of PC-3 cells (left) and the effects of the Akt inhibitor on the motility of PC-3 cells (right). In Array-A are PC-3 $3^{\mathrm{DEF} 6}$ cells and in Array- B are PC-3 ${ }^{\text {TGase4exp }}$ cells. Cells were treated with or without rhMDA-7 (shown at $10 \mathrm{ng} / \mathrm{ml}$ ), in the presence or absence of the Akt inhibitor (shown at $5 \mu \mathrm{M}$ ). 
and indeed, the MDA-7 receptor, may co-localize in normal and malignant human prostate tissues. Shown in Figure 5 (B, C and D), strong staining of TGase-4 was seen in the matrix and epithelial cells. Prostate tissues also showed staining of MDA-7 (Figure 5B and 5D) and IL-20Ra (Figure 5C). These observations demonstrated a good degree of co-localization between TGase-4, IL20Ra and MDA-7.

\section{Discussion}

The present study has shown that TGase-4 in human prostate cancer cells has a direct impact on the adhesive, motility and growth properties of the cell's response to rhMDA-7. Specifically, when not expressing TGase-4, cells responded well to rhDMA-7 by exhibiting a reduction of adhesion, motility and growth. However, cells expressing TGase-4 (either naturally - CA-HPV-10 or by forced expression $\left.-\mathrm{PC}-3^{\text {TGase } 4 \text { exp }}\right)$, had either no response to rhMDA-7 or had a marginal response opposite to those cells without TGase-4.

MDA-7/IL-24, although initially found to be up-regulated in melanoma cells $[16,17]$, has been shown to have a growth inhibitory role in certain cancer cells [17] which include ovarian [24], colorectal [25] and glioma cancer cells [26]. The present study has shown that the MDA-7/IL-24 cytokine also inhibits the adhesion, motility and growth of prostate cancer cells. These observations place MDA-7/IL-24 within the context of a limited number of cytokines that inhibit the adhesiveness, growth and migration of cancer cells.

The most intriguing finding of the present study was that the function of MDA-7 in prostate cancer cells appears to be dependent upon the presence of TGase-4. Using two cell models, i.e., the TGase-4 expressing CAHPV-10 and TGase-4 non-expressing PC-3 cells, we have shown that when TGase- 4 is not present, MDA-7

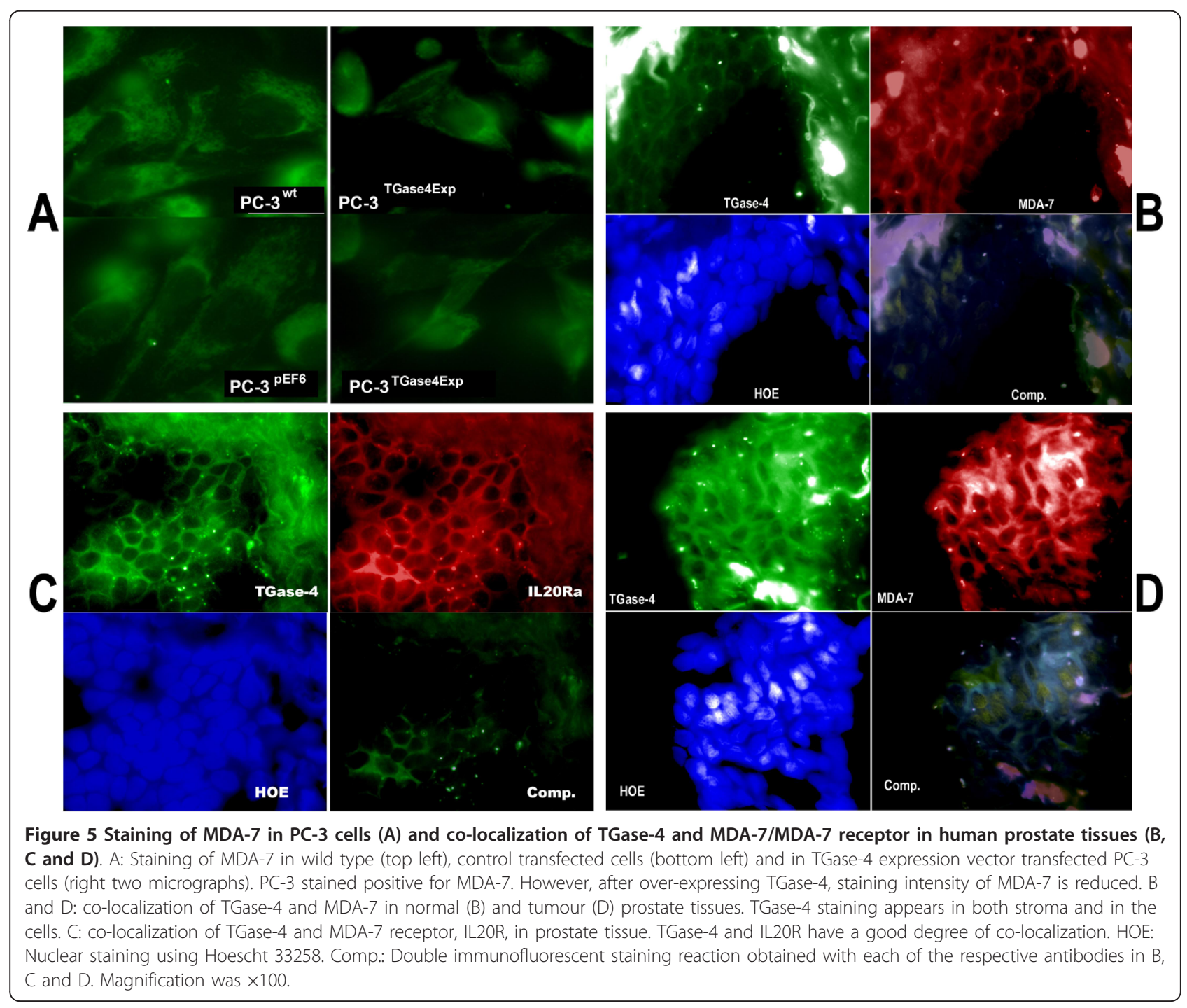


inhibits the migration of the cells (i.e., PC-3 wild type and control cells). When TGase-4 is expressed (in CAHPV -10 and PC- $3^{\text {TGase4exp }}$, cells no longer respond to MDA-7.

The mechanism(s) by which TGase-4 affects MDA-7 is not clear. MDA-7/IL-24 acts via its receptor -MDA7R/IL-24R. Receptor complexes include at least the IL20alpha and IL-20beta complex and the IL-22R and IL20Rbeta complex. Intracellular signalling pathways downstream of these receptors are not clear. MAPK pathways and the Fas-FasL pathway [26] have been implicated.

The present study has shown that blocking the Akt pathway using an Akt inhibitor abolishes MDA-7 induced inhibition of migration, thus indicating that Akt may be a potential pathway downstream of MDA-7. It is interesting to note that $\mathrm{PC}-3$ cells over-expressing TGase-4 did not respond to MDA-7 nor the Akt inhibitor. Furthermore, inhibitors to pathways including the PLC- $\gamma$, JAK, PKC pathway, and WASP pathways, have no obvious impact on the action of MDA-7. Together, this may suggest that TGase-4 interferes with the action of MDA-7 at a stage before receptor activation. From the immunofluorescent staining of TGase- 4 and MDA-7 receptor, it is clear that there is a good degree of colocalization between the TGase- 4 and IL-20Ra. A possibility thus exists that TGase-4 may interact with IL20Rs masking the site for MDA-7 to interact. More work is required to clarify the interaction of this possibility.

MDA-7 has been tested for its clinical application as an anti-cancer treatment option. Using an adenoviralbased delivery method, MDA-7 has been shown to have an anti-tumour effect in ovarian, lung, and hepatoma cancer models. MDA-7 has also been shown to increase the efficiency bevacizumab and Herceptin. Information on the effect of MDA-7 on prostate cancer cells is rather limited. However, it has been demonstrated that expression of MDA-7 in prostate cancer cells inhibits growth and induction of apoptosis [18]. Albeit, at an early stage, observations from the present study are interesting and have important clinical implications, e.g., therapeutic consideration of the use of MDA-7 would be dependent on the degree of expression of TGase-4. MDA-7 may be more sensitive in tumours that express low levels of TGase- 4 and vice versa. This is an interesting point to consider in future pre-clinical and clinical studies.

\section{Conclusion}

This study reports for the first time that the presence of TGase-4, a prostate specific TGase-4, has an overriding effect on a cells response to MDA-7, a potential anticancer cytokine. TGase-4, via mechanism(s) yet to be identified, blocked the action of MDA-7 in prostate cancer cells. This has an important implication when considering the use of MDA-7 in prostate cancer therapies.

\section{Acknowledgements}

The authors wish to thank Cancer Research Wales, Robert Benjamin Ablin Foundation for Cancer Research, and Albert Hung Foundation for supporting their work.

\section{Author details}

${ }^{1}$ Department of Pathology, University of Arizona College of Medicine, Arizona Cancer Center and BIO5 Institute, Tucson, Arizona, AZ 85724-5043 USA. ${ }^{2}$ Metastasis and Angiogenesis Research Group, Cardiff University School of Medicine, Cardiff, UK.

\section{Authors' contributions}

RJA and WGJ contributed to the study design, experimental work, and manuscript preparation. MDM and HGK contributed to sample collection and manuscript preparation. All of the authors read and approved the final manuscript.

\section{Competing interests}

The authors declare that they have no competing interests.

Received: 19 November 2010 Accepted: 28 April 2011 Published: 28 April 2011

\section{References}

1. Folk JE: Transglutaminases. Annu Rev Biochem 1980, 49:517-531.

2. Chen JSK, Mehta K: Tissue transglutaminase: an enzyme with a split personality. Int J Biochem Cell Biol 1999, 31:817-836.

3. Gentile V, Grant FJ, Porta R, Baldini A: Localization of the human prostate transglutaminase (type IV) gene (transglutaminase-4) to chromosome 3p21.33-p22 by fluorescence in situ hybridization. Genomics 1995, 27:219-220.

4. Grant FJ, Taylor DA, Sheppard PO, Mathewes SL, Lint W, Vanaja E, Bishop PD, O'Hara PJ: Molecular cloning and characterization of a novel transglutaminase cDNA from a human prostate cDNA library. Biochem Biophys Res Commun 1994, 203:1117-1123.

5. Dubbink HJ, de Waal L, van Haperen R, Verkaik NS, Trapman J, Romijn JC: The human prostate-specific transglutaminase gene (TGM4): genomic organization, tissue-specific expression, and promoter characterization. Genomics 1998, 51:434-44.

6. Dubbink HJ, Hoedemaeker RF, van der Kwast TH, Schroder FH, Romijn JC: Human prostate-specific transglutaminase: a new prostatic marker with a unique distribution pattern. Lab Invest 1999, 79:141-150.

7. An G, Meka CS, Bright SP, Veltri RW: Human prostate-specific transglutaminase gene: promoter cloning, tissue-specific expression, and down-regulation in metastatic prostate cancer. Urology 1999, 54:1105-1111.

8. Cho SY, Jeon JH, Kim CW, Shin DM, Jang GY, Jeong EM, Lee SE, Song KY, Kim IG: Monoclonal antibodies to human transglutaminase 4. Hybridoma (Larchmt) 2010, 29:263-267.

9. Ho KC, Quarmby VE, French FS, Wilson EM: Molecular cloning of rat prostate transglutaminase (type IV) gene (transglutaminase-4) to chromosome 3p21.33p22 by fluorescence in situ hybridization. Genomics 1995, 27:219-220.

10. Williams-Ashman HG: Transglutaminases and the clotting of mammalian seminal fluids. Mol Cell Biochem 1984, 58:51-61.

11. Ablin RJ, Whyard TC: Identification and biological relevance of spermatozoal transglutaminase. Experientia 1991, 47:277-279.

12. Davies G, Ablin RJ, Mason MD, Jiang WG: Expression of the prostate transglutainase (TGase-4) in prostate cancer cells and its impact on the invasiveness of prostate cancer. J Exp Therapeut Oncol 2007, 6:257-264.

13. Jiang WG, Ablin RJ, Kynaston HG, Mason MD: The Prostate Transglutaminase (TGase-4, TGaseP) regulates the interaction of prostate cancer and vascular endothelial cells, a potential role for the ROCK pathway. Microvas Res 2009, 77:150-157. 
14. Cho SY, Choi K, Jeon JH, Kim CW, Shin DM, Lee JB, Lee SE, Kim CS, Park JS, Jeong EM, Jang GY, Song KY, Kim IG: Differential alternative splicing of human transglutaminase 4 in benign prostate hyperplasia and prostate cancer. Exp Mol Med 2010, 42:310-318.

15. Jiang WG, Ablin RJ, Ye L, Kynaston, Mason MD: The prostate transglutaminase, TGase-4, coordinate with the HGFL/MSP-RON system in stimulating the migration of prostate cancer cells. Int J Oncology 2010, 37:413-418.

16. Jiang H, Lin JJ, Su ZZ, Goldstein NI, Fisher PB: Subtraction hybridization identifies a novel melanoma differentiation associated gene, mda-7, modulated during human melanoma differentiation, growth and progression. Oncogene 1995, 11:2477-2486.

17. Jiang H, Su ZZ, Lin JJ, Goldstein NI, Young CSH, Fisher PB: The melanoma differentiation associated gene mda-7 suppresses cancer cell growth. Proc Nat Acad Sci USA 1996, 93:9160-9165.

18. Lebedeva IV, Sarkar D, Su ZZ, Su Z-Z, Kitada S, Dent P, Stein CA, Reed JC, Fisher $\mathrm{PB}: \mathrm{BCl}-2$ and $\mathrm{BCl}-\mathrm{X}_{\mathrm{L}}$ differentially protect human prostate cancer cells from induction of apoptosis by melanoma differentiation associated gene-7, mda-7/L-24. Oncogene 2003, 22:8758-8773.

19. Jiang WG, Davies G, Martin TA, Parcc C, Watkins G, Mason MD, Mokbel K, Mansel RE: Molecular targeting of matrilysin and its impact on tumour growth in vivo, the potential implications in breast cancer therapy. Clin Cancer Res 2005, 11:6012-6019.

20. Jiang WG, Watkins G, Douglas-Jones A, Mokbel K, Mansel RE, Fodstad O: Expression of Com-1/p8 in human breast cancer, and its relevance to clinical outcome and ER status. Int I Cancer 2005, 117:730-737.

21. Giaever I, Keese CR: Micromotion of mammalian cells measured electrically. Proc Natl Acad Sci USA 1991, 88:7896-7900.

22. Jiang WG, Martin TA, Russell-Lewis J, Ye L, Douglas-Jones A, Mansel RE: Eplin-alpha expression in human breast cancer, the impact on cellular migration and clinical outcome. Mol Cancer 2008, 7:71.

23. Keese CR, Wegener J, Walker SR, Giaever I: Electrical wound-healing assay for cells in vitro. Proc Natl Acad Sci USA 2004, 101:1554-1559.

24. Gopalan B, Litvak A, Sharma S, Mhashilkar AM, Chada S, Ramesh R: Activation of the Fas-FasL signaling pathway by MDA-7/L-24 kills human ovarian cancer cells. Cancer Res 2005, 65:3017-3024.

25. Zhao L, Dong A, Gu J, Liu Z, Zhang Y, Zhang W, Wang Y, He L, Qian C, Qian Q, Liu X: The antitumor activity of TRAIL and IL-24 with replicating oncolytic adenovirus in colorectal cancer. Cancer Gene Ther 2006, 13:1011-1022.

26. Yacoub A, Mitchell C, Lebedeva IV, Sarkar D, Su ZZ, McKinstry R, Gopalkrishnan RV, Grant S, Fisher PB, Dent P: MDA-7 (IL-24) Inhibits growth and enhances radiosensitivity of glioma cells in vitro via JNK signaling. Cancer Biol Ther 2003, 2:347-353.

doi:10.1186/1479-5876-9-49

Cite this article as: Ablin et al:: Prostate transglutaminase (TGase-4) antagonizes the anti-tumour action of MDA-7/IL-24 in prostate cancer. Journal of Translational Medicine 2011 9:49.

\section{Submit your next manuscript to BioMed Central and take full advantage of:}

- Convenient online submission

- Thorough peer review

- No space constraints or color figure charges

- Immediate publication on acceptance

- Inclusion in PubMed, CAS, Scopus and Google Scholar

- Research which is freely available for redistribution

Submit your manuscript at www.biomedcentral.com/submit
Biomed Central 